\title{
Characterisation of Titanium Tetrachloride and Titanium Sulfate Flocculation in Wastewater Treatment
}

\author{
Y. Okour ${ }^{*}$, H.K. Shon ${ }^{*}$ and I. El Saliby * \\ *Faculty of Engineering and IT, University of Technology, Sydney, P.O. Box 123, Broadway, NSW 2007, \\ Australia (E-mail: yokour@eng.uts.edu.au; hkshon@eng.uts.edu.au; Ibrahim.elsaliby@eng.uts.edu.au) \\ The author to whom all the correspondence should be addressed (Tel.: +61295142641, Fax: \\ +61295142633). Email: hkshon@eng.uts.edu.au
}

\begin{abstract}
Flocculation with titanium tetrachloride $\left(\mathrm{TiCl}_{4}\right)$ and titanium sulfate $\left(\mathrm{Ti}\left(\mathrm{SO}_{4}\right)_{2}\right)$ was investigated in terms of different coagulant doses, $\mathrm{pH}$, turbidity, dissolved organic carbon (DOC), UV-254, colour, zeta potential, particle size and molecular weight distribution. The two coagulants were compared with the commonly used coagulants such as ferric chloride $\left(\mathrm{FeCl}_{3}\right)$ and aluminium sulfate $\left(\mathrm{Al}_{2}\left(\mathrm{SO}_{4}\right)_{3}\right)$. Titanium tetrachloride showed the highest turbidity removal, while titanium sulfate showed the highest reduction of UV-254 and colour at all pH values. The four coagulants were found to have similar organic removal up to $60-67 \%$ and resulted in similar organic removal in terms of various MW ranges. The decantability of the settled flocs was very high for titanium tetrachloride, titanium sulfate and ferric chloride compared with aluminium sulfate. The dominating coagulation mechanisms for titanium tetrachloride and titanium sulfate are still to be studied, since different precipitation reactions might take place at different $\mathrm{pH}$ even without flocculant addition. Titanium tetrachloride and titanium sulfate were found as effective new coagulants in wastewater treatment not only in terms of organic matter removal, but also in sludge reduction through the production of titanium dioxide.
\end{abstract}

Key Words: Aluminium sulfate; Floccualtion; Ferric chloride; Titanium sulfate; Titanium tetrachloride; Wastewater.

\section{INTRODUCTION}

Coagulation and flocculation processes are an important part of wastewater treatment. Coagulation or destabilization of a colloidal suspension results in aggregation of particles by physical and chemical processes. Flocculation leads to the formation of a larger settleable structure by bridging. This process is commonly used to remove suspended organic matter and colour. Commonly used coagulants include the following (1) aluminium sulfate (72\%), (2) iron salts (23\%) and (3) polyaluminum chlorides (5\%) (DeWolfe et al., 2003).

Aluminium sulfate is the most commonly used coagulant and is easy to handle and apply. Its main disadvantage is that it is most effective over a limited $\mathrm{pH}$ range of 6 to 8 (Adin et al., 1998). Ferric chloride is also a commonly used coagulant and is effective over a wider $\mathrm{pH}$ range of 4 to 10 . The ferric hydroxide floc is also heavier than the aluminium floc, improving its settling characteristics, and reducing the size of the clarifier. However, the flocculation process using these coagulants produces large quantities of sludge which inhibit efficient wastewater treatment. A coagulant that produces less sludge or more reusable sludge offers a better solution to many environmental and economical problems associated with sludge handling.

The possibility of using titanium compounds as coagulants in water treatment was first investigated by Upton and Buswell. (1937).They found that titanium sulfate appeared to have better fluoride removal due to a quadrivalent cation instead of the trivalent aluminium ion. Ilmenite extract gave 
much better coagulation in the coloured water high in colloidal matter and dissolved salts than aluminium or ferric sulfates. They observed that titanium salts appeared feasible from the standpoint of cost and the $\mathrm{pH}$ range for good floc formation. The titanium floc formed in a faster manner and in a bulkier appearance. On the other hand, titanium sulfate showed no advantage over aluminium sulfate regarding fluoride removal, but removed colour from water more efficiently. Lokshin and Belikov (2003) also investigated Ti-salt flocculation. They found that wastewater can be efficiently purified to remove fluoride ions with titanium (IV) compounds, especially with hydrated oxotitanium sulfate with $\left[\mathrm{F}^{-}\right]$concentration achieved of $0.5-0.6 \mathrm{mg} / \mathrm{L}$. They found that the concentration of the sulfate ions in purified water after titanium sulfate flocculation did not exceed the permissible limit at the optimum doses of wastewater purification.

In recent years, various new coagulants have been studied and developed including organic, inorganic and composite coagulants. Shon et al. (2007) reported the use of Ti-salt as a new coagulant was efficient and economical not only in terms of organic matter removal, but also in sludge reduction. They studied titanium tetrachloride as an alternative coagulant to remove particulate and dissolved organic matter from wastewater. Titanium tetrachloride successfully removed organic matter to the same extent as ferric and aluminium salts. The settling of titanium sludge was faster which made the subsequent separation process easier. After flocculation with titanium salts, the settled floc was incinerated to produce titanium dioxide $\left(\mathrm{TiO}_{2}\right)$, which had competitive quality characteristics as that of commercially available $\mathrm{TiO}_{2}$. As sludge containing titanium salts was produced in significant quantities in wastewater treatment plants, sludge associated environmental problems will be hindered and the $\mathrm{TiO}_{2}$ demand can be met in many other applications.

In this study, characterisations of titanium tetrachloride and titanium sulfate coagulants were investigated in terms of turbidity, dissolved organic carbon (DOC), UV-254 absorbance, colour, zeta potential, particle size, and molecular weight distribution. The performance of titanium salt coagulants was compared with ferric chloride and aluminium sulfate coagulants.

\section{MATERIALS AND METHODS}

\section{Synthetic wastewater}

Table 1 shows the compounds of synthetic wastewater (SWW) used in this study. This wastewater represents biologically treated sewage effluent in a wastewater treatment plant (Seo et al., 1997). Tannic acid, sodium lignin sulfonate, sodium lauryle sulfate, peptone and arabic acid contributed to the large MW size organic matter, while the natural organic matter (NOM) from tap water, peptone, beef extract and humic acid consisted of the small MW organic matters. 
Table 1. Constituents of the synthetic wastewater used in this study, all compounds were dissolved in tap water

\begin{tabular}{lccc}
\hline Compounds & $\begin{array}{c}\text { Concentration } \\
(\mathrm{mg} / \mathrm{L})\end{array}$ & $\begin{array}{c}\text { Molecular weight } \\
\text { (Daltons) }\end{array}$ & $\begin{array}{c}\text { Fraction } \\
\text { organic matter }\end{array}$ \\
\hline Beef extract & 1.8 & $300,100,70$ & 0.065 \\
Peptone & 2.7 & $34300,100,80$ & 0.138 \\
Humic acid & 4.2 & 1500,300 & 0.082 \\
Tannic acid & 4.2 & 6300 & 0.237 \\
Sodium lignin sulfonate & 2.4 & 12100 & 0.067 \\
Sodium lauryle sulphate & 0.94 & 34300 & 0.042 \\
Arabic gum powder & 4.7 & 900,300 & 0.213 \\
Arabic acid & 5.0 & 38900 & 0.156 \\
(polysaccharide) & & & \\
(NH$)_{2} \mathrm{SO}_{4}$ & 7.1 & 0 & 0 \\
$\mathrm{~K}_{2} \mathrm{HPO}_{4}$ & 7.0 & 0 & 0 \\
$\mathrm{NH}_{4} \mathrm{HCO}_{3}$ & 19.8 & 0 & 0 \\
$\mathrm{MgSO}_{4} \cdot 7 \mathrm{H}_{2} \mathrm{O}$ & 0.71 & 0 & 0 \\
\hline
\end{tabular}

\section{Jar test procedure}

A conventional jar test procedure was applied at different coagulant doses $(10-60 \mathrm{mg} / \mathrm{L})$ and $\mathrm{pH}$ conditions ( $\mathrm{pH} 4-10)$. For each jar test, six 1 litre beakers were filled with SWW. Then they were mixed with different doses of coagulants. Rapid mixing was carried out for 1 minute, and then the mixing speed was reduced to $30 \mathrm{rpm}$ for 30 minutes. The mixers were turned off to allow for the settling of aggregated floc for 50 minutes. Samples were drawn from $5 \mathrm{~cm}$ below water surface without disturbing the sediment in the sample. The $\mathrm{pH}$ was adjusted with $0.1 \mathrm{~N}$ solution of hydrochloride acid and sodium hydroxide prior to coagulant addition. Coagulants used were 1\% (w/v) solution of aluminium sulfate, ferric chloride, titanium sulfate, and titanium tetrachloride. Deionised water was used to produce stock solutions of different coagulants.

\section{Turbidity and zeta potential}

A turbidimeter (HACH 2100P, USA) was used to measure the turbidity. Amount of $25 \mathrm{ml}$ of the supernatant of each coagulant was taken for the turbidity measurement after 50-minutes settling period. Measurements for the turbidity for each coagulant were taken three times and the mean value was recorded. Zeta potential was measured using (Zeta sizer $3000 \mathrm{~m}$, Malvern, UK) to support the assumption of complete charge neutralization. For each sample, the instrument automatically made triplicate measurements, and a mean value was recorded. Measurements for zeta potential were undertaken twice for each sample and a mean value of the two measurements were taken as a result.

\section{DOC, UV-254 absorbance and colour}

DOC was measured by using the UV-persulfate TOC analyser (Multi NC2000, Analytikjena, Germany). All samples were filtered through $0.45 \mu \mathrm{m}$ membrane prior to the DOC measurement. UV absorbance at $254 \mathrm{~nm}$ was determined with a UV-vis spectrophotometer ( $\mathrm{N} \mathrm{595,} \mathrm{Shimadzu,}$ Kyoto, Japan) in a $1 \mathrm{~cm}$ quartz cell. Colour was measured using a spectrophotometer (DR/2000, HACH Spectrophotometer, USA). The $\mathrm{pH}$ meter (Orion, model 920A) was used to adjust solutions' $\mathrm{pH}$.

\section{Molecular weight (MW) and particle size distribution}

After each treatment, the superannuants were subjected to MW distribution measurement. High pressure size exclusion chromatography (HPSEC, Shimadzu, Corp., Japan) with a SEC column 
(Protein-pak125, Waters, Milford, USA) was used to determine the MW distributions of organic matter (OM). Standards of MW of various polystyrene sulfonates (PSS: 210, 1800, 4600, 8000 and $18000 \mathrm{Da}$ ) were used to calibrate the equipment. The floc size distribution was investigated with a laser particle size analyser (LS-230, Beckman Coulter, USA) to determine the particle size distribution for the four coagulants.

\section{RESULTS AND DISCUSSION}

\section{Turbidity removal}

The effectiveness of the flocculation process can be measured by the percentage of turbidity residual. Figure 1 shows residual turbidity ratio as a function of the four coagulant doses at different $\mathrm{pH}$.

At $\mathrm{pH} 4$, aluminium sulfate did not remove the turbidity. This may be due to solubility of aluminium hydroxide at $\mathrm{pH} 4$. According to DeWolfe et al. (2003), the use of coagulants containing $\mathrm{Al}$ (III) is limited to $\mathrm{pH}$ above 5 because the solubility of amorphous aluminium hydroxide is increased for $\mathrm{pH}$ less than 5 . On the other hand, titanium tetrachloride showed better performance for the turbidity removal compared to the ferric chloride. The optimum dose for ferric chloride was $20 \mathrm{mg} / \mathrm{L}$ with turbidity ratio of 0.25 (turbidity removal of $75 \%$ ). Whereas the optimum dose for titanium tetrachloride and titanium sulfate were $30 \mathrm{mg} / \mathrm{L}$ and $40 \mathrm{mg} / \mathrm{L}$ with total turbidity removal of $77 \%$ and $73 \%$, respectively.

At $\mathrm{pH}$ 6, the optimum dose for the ferric chloride and the aluminium sulfate were $20 \mathrm{mg} / \mathrm{L}$ and 30 $\mathrm{mg} / \mathrm{L}$ with turbidity ratio of 0.25 and 0.24 , respectively. Titanium tetrachloride showed better turbidity ratio of 0.23 at optimum dose of $30 \mathrm{mg} / \mathrm{L}$, whereas titanium sulfate showed less turbidity performance (0.27) than aluminium sulfate and ferric chloride with optimum dose of $50 \mathrm{mg} / \mathrm{L}$. At $\mathrm{pH} 8$, titanium tetrachloride and aluminium sulfate exhibited the highest turbidity removal with the same turbidity ratio of 0.24 at optimum doses of $40 \mathrm{mg} / \mathrm{L}$ and $50 \mathrm{mg} / \mathrm{L}$, respectively compared with ferric chloride (optimum dose $=30 \mathrm{mg} / \mathrm{L}$, turbidity ratio $=0.28$ ) and titanium sulfate (optimum dose $=50 \mathrm{mg} / \mathrm{L}$, turbidity ratio $=0.29)$. At $\mathrm{pH} 10$, titanium tetrachloride, titanium sulfate and ferric chloride showed similar turbidity removal with turbidity ratio of 0.29 at optimum doses of 50 $\mathrm{mg} / \mathrm{L}, 60 \mathrm{mg} / \mathrm{L}$ and $40 \mathrm{mg} / \mathrm{L}$, respectively. While aluminium sulfate indicated less turbidity removal with turbidity ratio of 0.32 at optimum dose of $50 \mathrm{mg} / \mathrm{L}$.

In general, it can be seen that the turbidity removal with different coagulants at different $\mathrm{pH}$ followed a similar pattern for titanium tetrachloride and ferric chloride. Titanium tetrachloride and ferric chloride had minimal turbidity ratios for doses of 30-40 mg/L and 20-30 mg/L, at pH 4 and 6, respectively, then the turbidity increased dramatically. This indicates that adsorption and charge neutralization is taking place due to the colloids restabilizing. On the other hand, titanium sulfate and aluminium sulfate showed a continual decrease in turbidity ratio with an increase in the coagulant dose at all $\mathrm{pH}$ values except for $\mathrm{pH}$ 4. This trend is a sign that sweep flocculation is the main coagulation mechanism occurring. In general, sweep coagulation is thought to predominate for aluminium sulfate and titanium sulfate at doses above $50 \mathrm{mg} / \mathrm{L}$ for $\mathrm{pH}$ of 6,8 and 10 .

At high $\mathrm{pH}$ values higher coagulant doses were needed. Increase of the $\mathrm{pH}$ promoted deprotonation of organic substances so that negatively charged species were increased (O’Melia et al., 1999). The optimum turbidity doses for titanium tetrachloride were always less than aluminium sulfate. This may be due to the quadrivalent cation for titanium tetrachloride instead of the trivalent aluminium ion. Thus, colloid destabilisation and the formation of settleable floc can both be expected to be 
achieved at lower dosage than aluminium sulfate. On the other hand, the optimum turbidity doses for ferric chloride were also less than for aluminium sulfate, this is due to the fact that ferric chloride presents more active positive charges than hydrated aluminium sulfate (Mesdaghinia et al., 2006).

Adin et al. (1998) used secondary sewage effluent from activated sludge plant to investigate the flocculation of ferric chloride and aluminium sulfate. They indicated that turbidity removal of $86 \%$ for ferric chloride occurred at $\mathrm{pH} 4-5$ and optimum doses of $20-30 \mathrm{mg} / \mathrm{L}$. Whilst, the turbidity removal for aluminium sulfate was $90 \%$ occurred at $\mathrm{pH}$ 6-7 with doses higher than $30 \mathrm{mg} / \mathrm{L}$. On the other hand, Musikavong et al. (2005) found the turbidity removal of aluminium sulfate and ferric chloride dosages of $10 \mathrm{mg} / \mathrm{L}$ at uncontrolled $\mathrm{pH}$ was approximately $85 \%$ for treated industrial wastewater. Our results are in good agreement with the previous. However, the turbidity removal for the four coagulants was in the range of (71-76\%) compared with (85-90\%) for the previous studies.
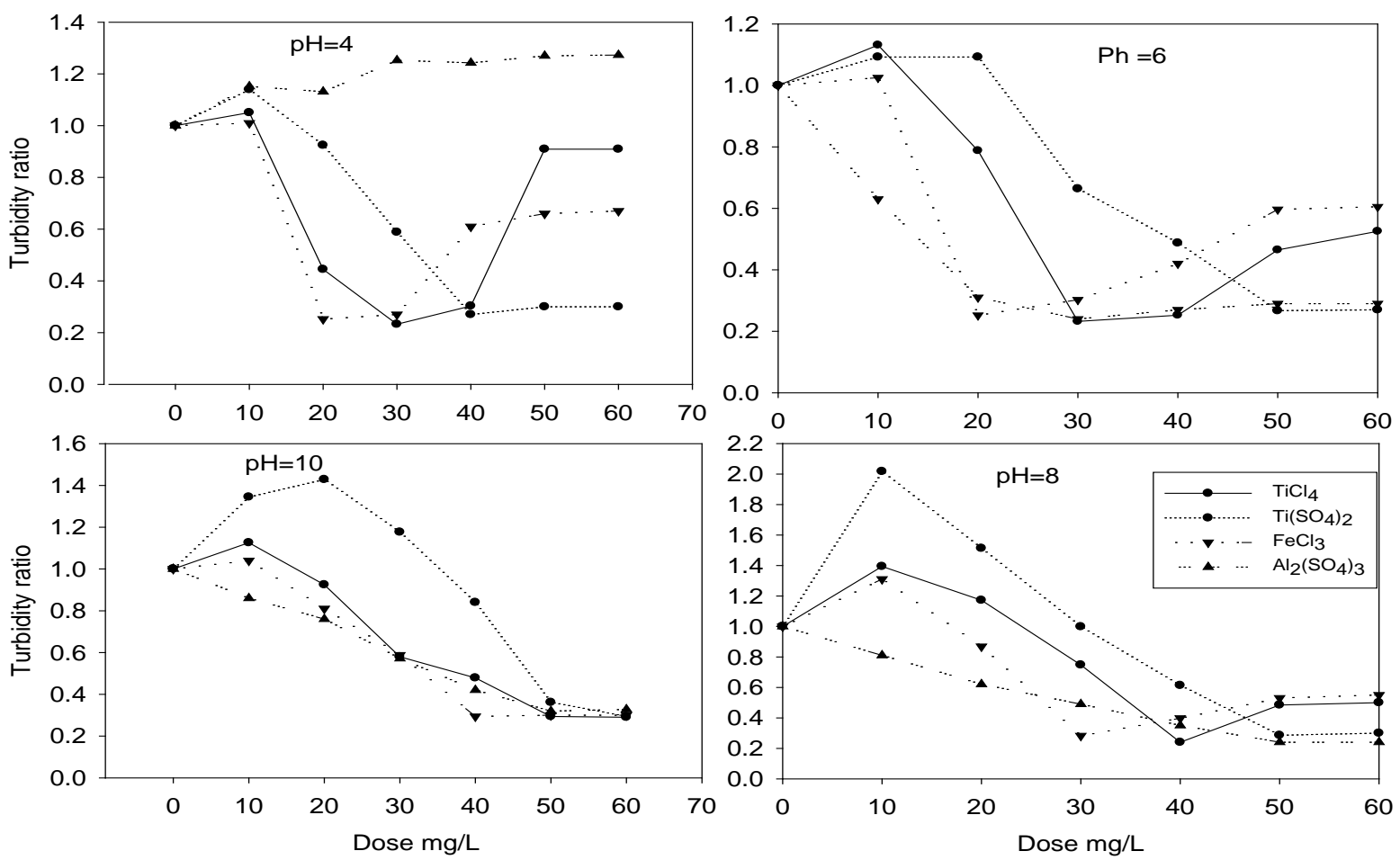

Figure1. Variation in residual turbidity ratio as a function of different coagulant doses at variable $\mathrm{pH}$.

\section{Organic matter removal}

Historically, coagulation process was arranged to remove turbidity, typically related to pathogens occurrence, but recently it is used to remove DOC. Organic removal was examined in terms of DOC removal and UV absorbance at a wavelength of $254 \mathrm{~nm}$. In this study, DOC data is presented in Figure 2. DOC was gradually reduced from the average value of about $10 \mathrm{mg} / \mathrm{L}$ to approximately 3.3-3.8 $\mathrm{mg} / \mathrm{L}$ by titanium tetrachloride, titanium sulfate, ferric chloride and aluminium sulfate at dosages of 30, 40, 20 and $30 \mathrm{mg} / \mathrm{L}$, respectively. The range of DOC removal of $\mathrm{pH} \mathrm{4-8} \mathrm{was} \mathrm{around}$ $62-67 \%$. Moreover, DOC was reduced from the average value of $10 \mathrm{mg} / \mathrm{L}$ to a level of $4.0 \mathrm{mg} / \mathrm{L}$ (approximately 60\% reduction), by titanium tetrachloride, ferric chloride and aluminium sulfate at $\mathrm{pH} 10$ with doses of 50, 40, and $50 \mathrm{mg} / \mathrm{L}$ respectively. On the other hand, titanium sulfate showed the minimum residual DOC ratio of 0.36 (maximum reduction of 64\%) at a dose of $60 \mathrm{mg} / \mathrm{L}$. 
The results of UV-254 reduction (aromaticity of water) for the four coagulants carried out at different $\mathrm{pH}$ values are given in Figure 3. At the same $\mathrm{pH}$ range of 4-10, titanium tetrachloride had minimum UV ratio between 0.10 and 0.16 that occurred at doses ranging from 30 to $50 \mathrm{mg} / \mathrm{L}$. While, titanium sulfate had the minimum UV-254 absorbance ratio from 0.1 to 0.12 , which occurred for doses above $50 \mathrm{mg} / \mathrm{L}$. In general, titanium salts showed maximum removal of aromatic compounds at doses between 40 and $50 \mathrm{mg} / \mathrm{L}$. For ferric chloride, the maximum UV-254 absorbance was obtained for dosage ranges of 20 to $30 \mathrm{mg} / \mathrm{L}$ at $\mathrm{pH}$ values between 4 and 6 , the optimum dose was $20 \mathrm{mg} / \mathrm{L}$ at $\mathrm{pH} 6$ with $0.1 \mathrm{UV}$ ratio. For aluminium sulfate, the $\mathrm{pH}$ range for high and positive removal is narrower than that of the other coagulants. The best performance for UV absorbance was around $\mathrm{pH}$ of 6 to 8, with aluminium sulfate dosage of $30 \mathrm{mg} / \mathrm{L}$ and higher. The optimum dose was $30 \mathrm{mg} / \mathrm{L}$ with UV ratio of 0.11 at $\mathrm{pH} 6$.
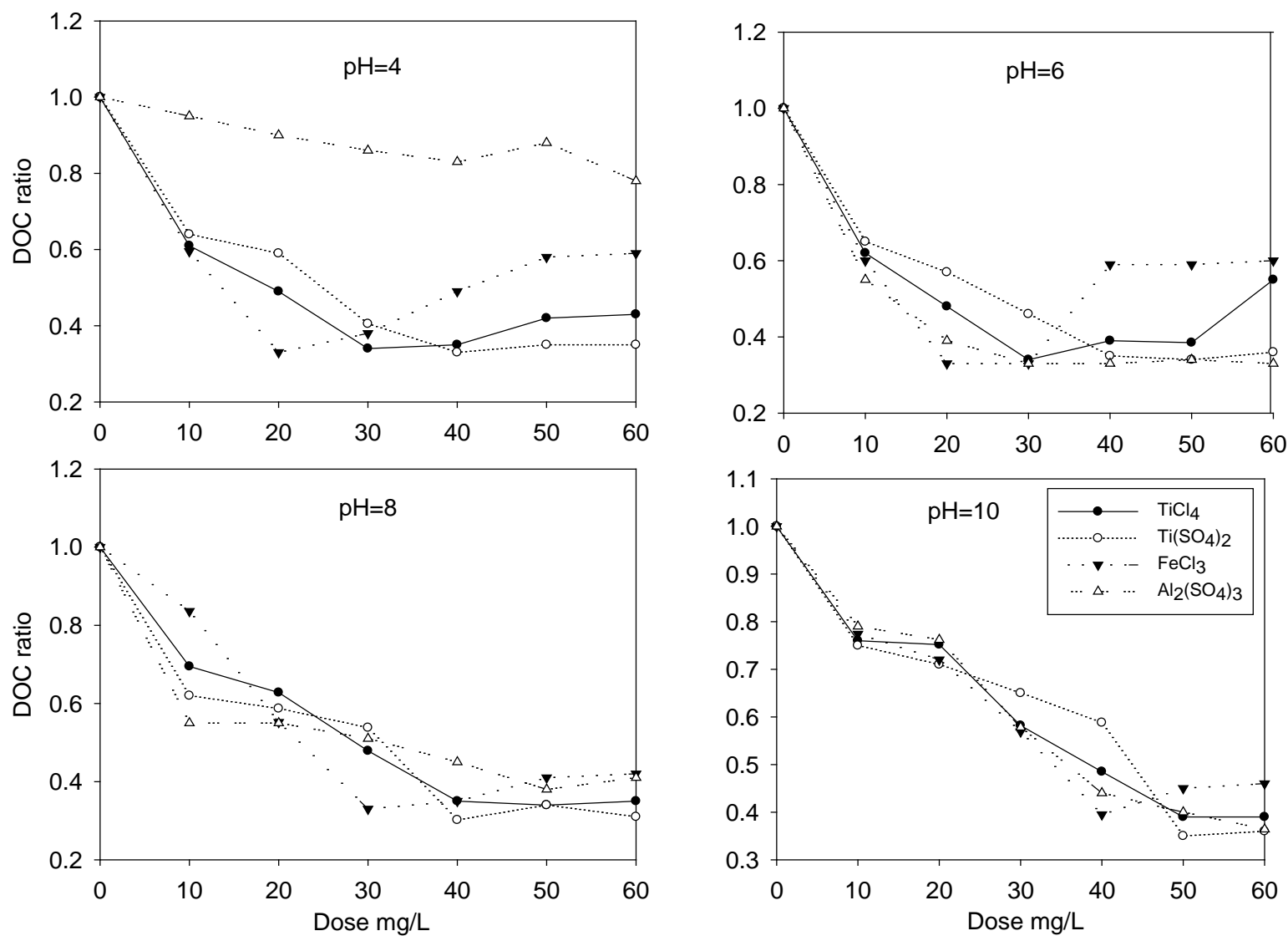

Figure 2. Variation of residual DOC ratio as a function of coagulants doses at different $\mathrm{pH}$. Initial DOC was equal to $10 \mathrm{mg} / \mathrm{L}$.

Titanium tetrachloride and titanium sulfate solutions were more acidic than aluminium sulfate solution. The alkalinity consumed during the formation of the titanium hydroxides was higher than with aluminium sulfate. As a result, for a similar coagulant dosage, the coagulation $\mathrm{pH}$ would be lower with titanium salts than with aluminium sulfate. The low $\mathrm{pH}$ by increasing the positive charge of the coagulant species, favours the adsorption of organics onto titanium hydroxides. Thus, higher removal efficiencies for DOC and UV-254 were achieved by titanium tetrachloride and titanium sulfate. On the other hand, ferric chloride consistently outperformed aluminium sulfate, although the shapes of the curves were quite similar. This is probably due to the high cationic charge of $\mathrm{FeCl}_{3}$ in contrast to the aluminium sulfate. Positively charged coagulant species could complex negatively charged functional groups forming NOM precipitates that can be removed in subsequent solids' separation processes. 
Coagulation $\mathrm{pH}$ is dependent on the coagulant type and the treated wastewater sample. Because the optimal $\mathrm{pH}$ for NOM removal is around 5 (Childress et al. 1999), lowering the $\mathrm{pH}$ to 4 enhanced the removal of DOC and UV-254 absorbance. Coagulation $\mathrm{pH}$ appeared to be a determining factor for maximum NOM removal and a better removal was obtained at $\mathrm{pH} 4$ than at other $\mathrm{pH}$ values. Thus, it could be concluded that readjustment of the coagulant $\mathrm{pH}$ to 4 reduces the coagulant dose and hence the production of the sludge. DOC and UV-254 reduction by coagulation is highly dependent on the humic fraction of NOM in the wastewater.
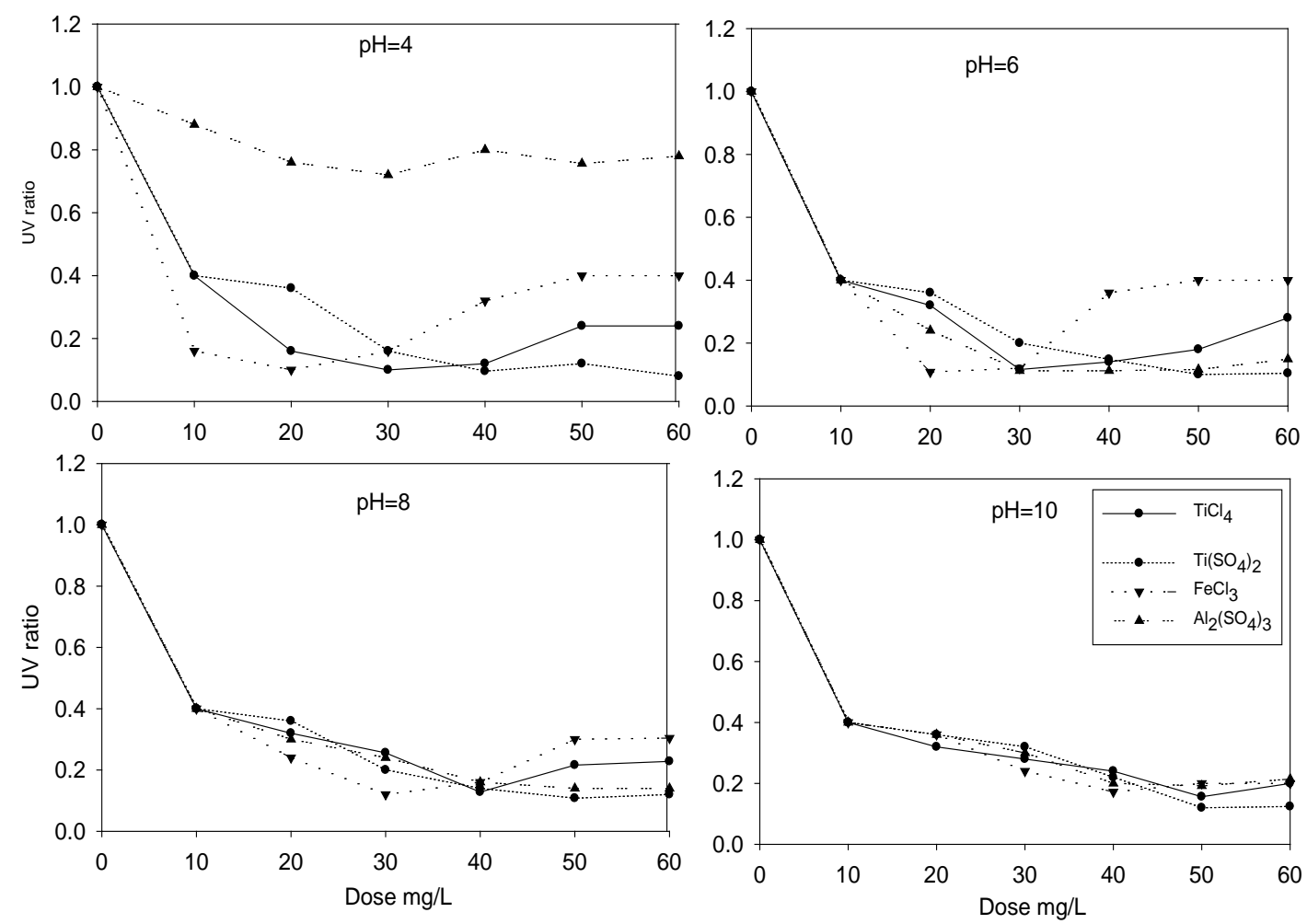

Figure 3. Variation of UV-254 absorbance ratio as a function of coagulants doses at different pHs.

\section{Specific UV absorbance (SUVA) removal}

Specific ultraviolet absorbance (SUVA) values are determined by dividing the UV-254 values by the DOC values and multiplying by 100 (Edzwald and Van Benschoten, 1990). The concept of specific UV absorbance (SUVA) has been developed as an operational indicator of the nature of NOM and the effectiveness of coagulation in removing NOM and DOC (Edzwald and Tobiason, 1999). SUVA values offered a simple characterisation of the nature of the NOM based on measurements of UV absorbance and DOC. The humic fraction, which absorbs UV light at $254 \mathrm{~nm}$, is more effectively removed by coagulation than the non humic fraction. The SUVA represents the amount of NOM considered to be humic in nature.

Pernitsky and Edzwald (2006) stated that for wastewater with low SUVA (2 or less), DOC will not control coagulant dose. For water supplies with SUVA greater than 2, the amount of NOM typically exerts a greater coagulant demand than the amount of particles. For these wastewaters, the required coagulant dose increases with increasing DOC. For this synthetic wastewater, SUVA value was determined to be around 2.50 (mg/L.m), confirming that the organic matter is a mixture of humics and other NOM, either hydrophobic or hydrophilic with molecular weights (MWs) 
ranging from low to high. Therefore, DOC removal accomplishes well and NOM influences coagulation.
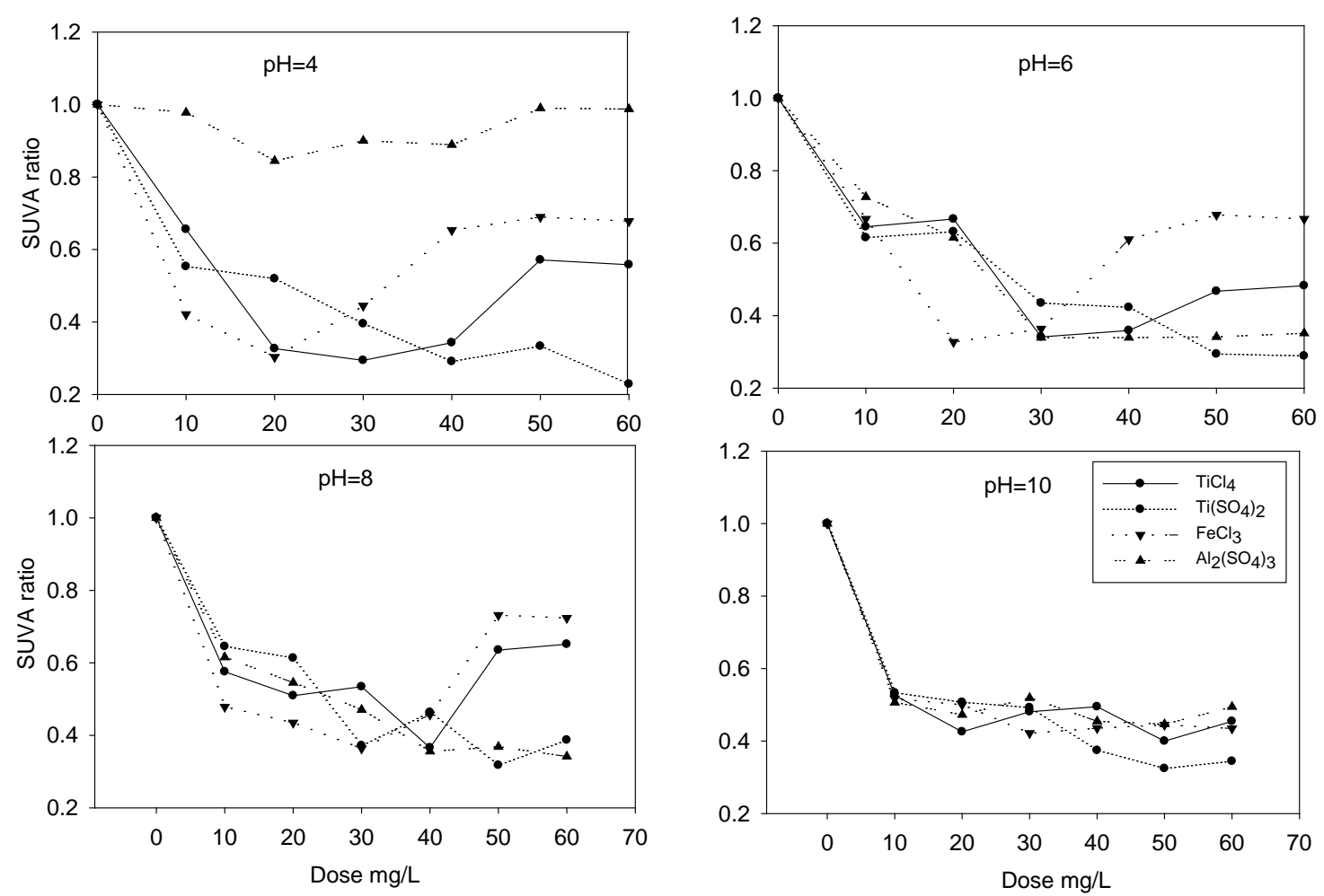

Figure 4. Variation of SUVA ratio as a function of coagulants doses at different $\mathrm{pH}$.

It can be seen from Figure 4, that titanium tetrachloride and ferric chloride showed minimum SUVA ratio in the same $\mathrm{pH}$ range of 4-8. The optimum doses for titanium tetrachloride were between 30 and $50 \mathrm{mg} / \mathrm{L}$. The best SUVA removal was $71 \%$ with dosage $30 \mathrm{mg} / \mathrm{L}$ at $\mathrm{pH} 4$. For ferric chloride the optimum dosages were between 20 and $30 \mathrm{mg} / \mathrm{L}$.The maximum SUVA removal was $70 \%$ at $\mathrm{pH}$ 4.The positive SUVA removal for titanium sulfate occurred at all $\mathrm{pH}$ ranges (4-10) was between 66 and $71 \%$ with coagulant dosage $\geq 50 \mathrm{mg} / \mathrm{L}$. The coagulation performance for the titanium salts (titanium tetrachloride and titanium sulfate) was less sensitive to $\mathrm{pH}$ (between $\mathrm{pH} 4$ and 8). Aluminium sulfate has also high SUVA removal with doses $\geq 30 \mathrm{mg} / \mathrm{L}$, but for a limited $\mathrm{pH}$ range (6-8). The best performance was at dose $30 \mathrm{mg} / \mathrm{L}$ with SUVA removal of more than $66 \%$. In general, all the four coagulants had a SUVA removal between $65-71 \%$.

\section{Residual colour removal}

Figure 5 shows the effect of coagulation on colour removal. As can be seen from figure 5 , the percentage of colour removal increased when coagulants' doses were raised. Titanium sulfate had a colour ratio of zero ( $100 \%$ colour removal) at all $\mathrm{pH}$ values with doses $\geq 50 \mathrm{mg} / \mathrm{L}$. In general, all four coagulants performed very well at $\mathrm{pH} 10$ with residual colour ratio between (0.03-0.08) which means 92 to $97 \%$ of colour removal. At pH 4 and 6, titanium tetrachloride had a minimum colour ratio of 0.04 compared with 0.30 for ferric chloride and 0.24 for aluminium sulfate at $\mathrm{pH}$ 6. At $\mathrm{pH}$ 8 , titanium tetrachloride and aluminium sulfate had the same colour ratio of 0.10 at doses of 40 and $50 \mathrm{mg} / \mathrm{L}$.

Asilian et al. (2006) stated that $99 \%$ of the colour was removed with synthetic wastewater using aluminium sulfate and ferrous sulfate coagulants at neutral $\mathrm{pH}$. Our results showed that all the four 
coagulants performed very well at neutral $\mathrm{pH}$ with colour removal above 90\%.Titanium sulfate had $100 \%$ colour removal at all $\mathrm{pH}$ values. Coagulation successfully removes substances producing colour which consist of colloidal metallic hydroxides and/or organic compounds. Coagulants can agglomerate the very small particles into lager sizes that can be settable or removed by absorption (Corbitt et al., 1998; Aziz et al., 2007)
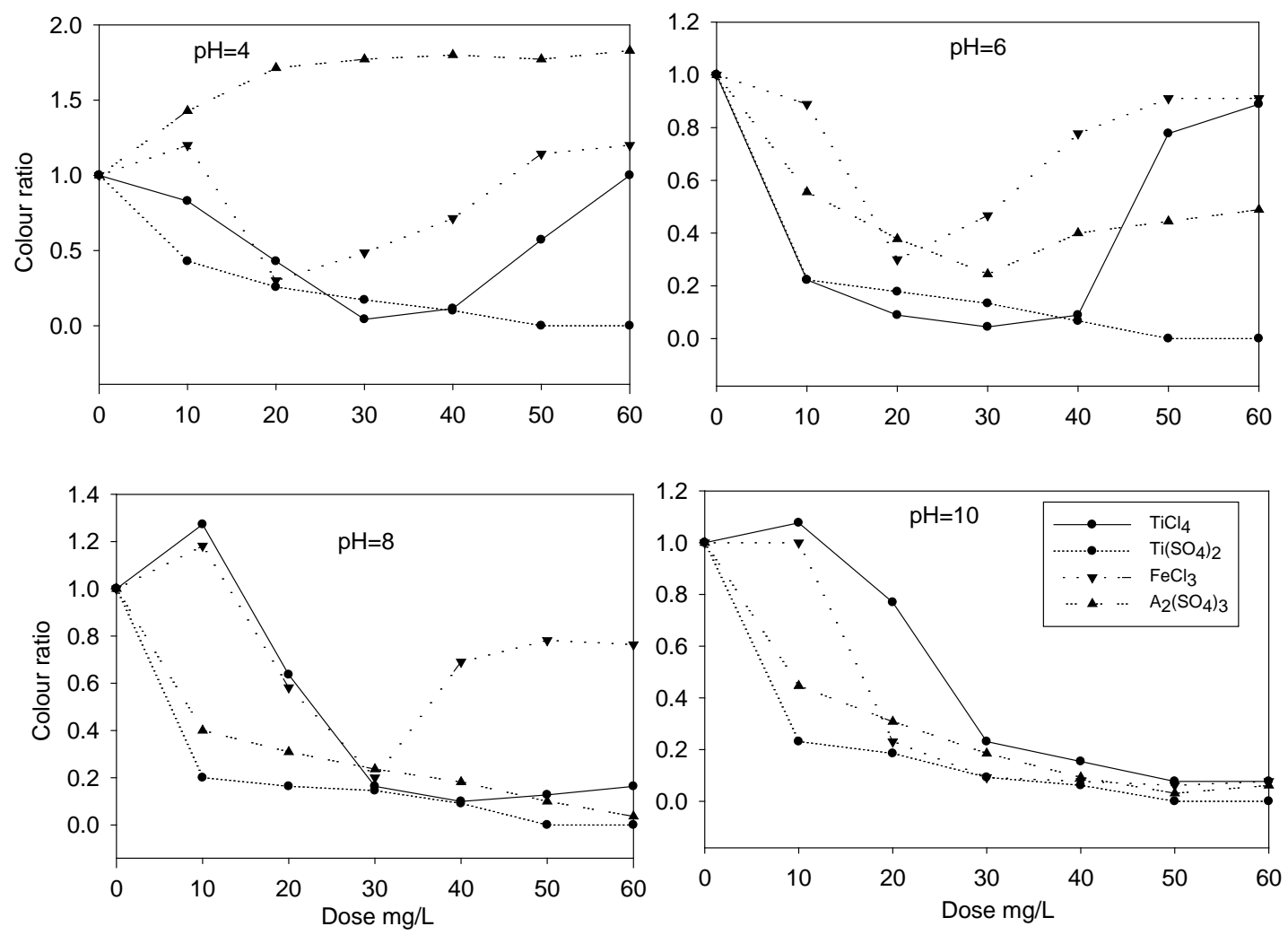

Figure 5. Variation in residual colour ratio as a function of coagulant doses at different pH.

\section{MW distribution}

MW distribution of organic matter is one of the important parameters in characterising organic matter (Amy et al., 1992; Newcombe et al., 1997). For example, some investigators have suggested that coagulation is suitable to treat higher MW fraction of organic matter. In addition to the amount of organic matter present, the nature of the organic matter has a signification effect on whether organic matter controls coagulant dosages and on how much organic matter is removed by coagulation. All four coagulants resulted in similar organic removal in terms of various MW ranges. They removed all the large MW organic matter (25870 Da). Moreover, this coagulation also helped in removing some of the small MW compounds (635-415 Da) (figure is not shown).

\section{Zeta potential}

The measure of coagulant effects is indicated by zeta potential. Coagulation generally occurs when zeta potential is lowered to less than $+/-0.5 \mathrm{mV}$ (DeWolfe et al., 2003). Although zeta potential is used for measuring the charge for coagulation, it should never be the sole measure of determining coagulant dosage. In fact zeta potential is more of a confirmation of the observations of jar testing. Zeta potential allows for optimisation of dose, but then so does a jar test, without the expensive analyser. 

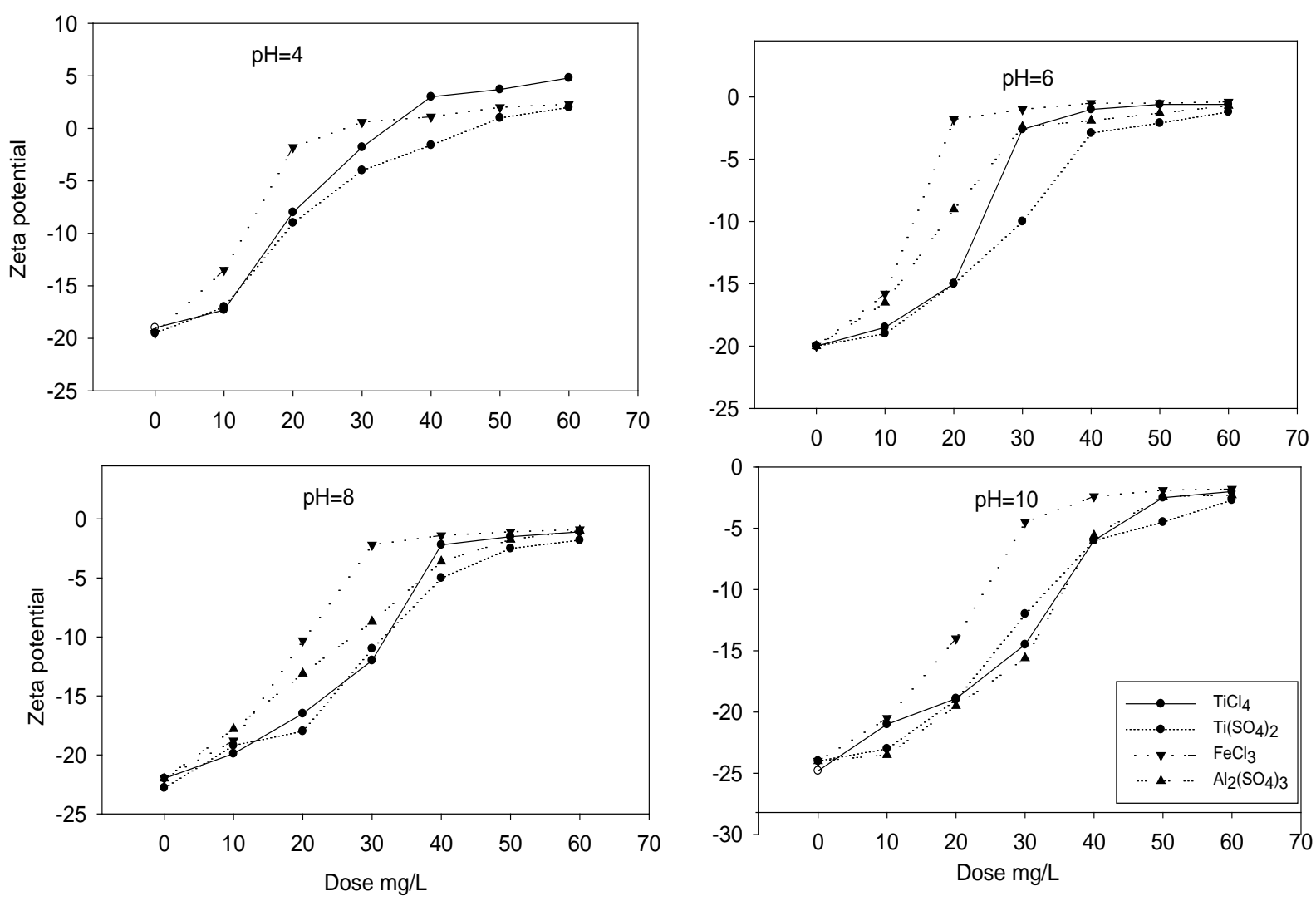

Figure 6. Variation of zeta potentials as a function of coagulants doses at different $\mathrm{pH}$.

Bernhardt and Schell (1993) suggested that the optimal coagulation performance occurred at the coagulant dose that related to the complete charge neutralisation. At $\mathrm{pH} 4$, as titanium tetrachloride and ferric chloride doses were increased, zeta potential for both became less negative and reached positive values. This positive trend of zeta potential suggested that charge neutralization induced the precipitation through adsorption and/or deposition of positively charged hydroxides onto the negatively charged particles surfaces. This mechanism is called charge neutralization.

Titanium tetrachloride and ferric chloride both showed the same mechanism of sweep coagulation by precipitation of solid titanium and ferric hydroxide at $\mathrm{pH} 8$ and 10. Figure 6 shows a decline in the absolute values of zeta potential reaching a minimum at the optimum doses and then decreased slightly. For aluminium sulfate, the most important mechanism is sweep coagulation. Zeta potential showed a decrease in the absolute values at $\mathrm{pH} \mathrm{6,8}$ and 10. This is probably due to the interaction of the positively charged aluminium hydroxide with negatively charged colloids. Aluminium sulfate and titanium sulfate had the same mechanism except at $\mathrm{pH} 4$. Zeta potential indicates domination of destabilization by adsorption of positive titanium hydroxide to produce charge neutralization at $\mathrm{pH}$ 4. According to DeWolfe et al. (2003), coagulants with high sulfate concentration usually have a broader $\mathrm{pH}$ range for sweep flocculation because, when sulfate particles are collided, the electrostatic repulsion is decreased and allows particles to adhere to each others.

In fact, the dominating coagulation mechanisms for titanium tetrachloride and titanium sulfate are still to be studied, since different precipitation reactions might take place at different $\mathrm{pH}$ values even without flocculant addition. Unfortunately, there is no specific study that examines the liquid phase hydrolysis reaction of titanium tetrachloride and titanium sulfate. Depending on $\mathrm{pH}$, titanium tetrachloride $\left(\mathrm{TiCl}_{4}\right)$ produces $\mathrm{TiOCl}_{2}$ in wastewater then hydrolyses to $\mathrm{Ti}(\mathrm{OH})_{4}$. As the zeta 
potential of the negatively charged organic matter is broken by $\mathrm{Ti}(\mathrm{OH})_{4}$, organic matter aggregates with the $\mathrm{Ti}(\mathrm{OH})_{4}$ (Kapias and Griffiths, 2005). A precipitate of titanium hydroxide is formed that can physically sweep the colloidal particles from the suspension.

\section{Particle size distribution}

Figure 7 shows the particle size distribution of the settled flocs after different flocculation. The particle size after $\mathrm{TiCl}_{4}$ and $\mathrm{Ti}\left(\mathrm{SO}_{4}\right)_{2}$ flocculation ranged from 17.2-176 $\mu \mathrm{m}$ and 17.2-236 $\mu \mathrm{m}$, respectively. The particle size after $\mathrm{FeCl}_{3}$ and $\mathrm{Al}_{2}\left(\mathrm{SO}_{4}\right)_{2}$ flocculation ranged from 13.9-153 and 5.8$73.8 \mu \mathrm{m}$, respectively. $7.1 \%$ of the settled floc after $\mathrm{TiCl}_{4}$ flocculation included $73.8 \mu \mathrm{m}$ of particle size. $6.5 \%$ of the settled floc after $\mathrm{FeCl}_{3}$ flocculation had the similar particle size. $6.2 \%$ and $5.9 \%$ of settled floc after $\mathrm{Ti}\left(\mathrm{SO}_{4}\right)_{2}$ flocculation consisted of 79.3 and $132 \mu \mathrm{m}$ of particle sizes, respectively. $6.3 \%$ and $6.1 \%$ of the settled floc after $\mathrm{Al}_{2}\left(\mathrm{SO}_{4}\right)_{3}$ flocculation included 35.7 and $21.4 \mu \mathrm{m}$, respectively. The mean size of titanium tetrachloride, titanium sulfate, ferric chloride and aluminium sulfate was $81.99,63.01,50.88$ and $26.29 \mu \mathrm{m}$ respectively. This suggests that the floc size of Ti-salt flocculation is bigger than that of iron- and aluminium-salt flocculation. This bigger floc size is helpful to rapidly settle the coagulated floc down. Therefore, the high decantability for the settled floc after $\mathrm{TiCl}_{4}$ and $\mathrm{Ti}\left(\mathrm{SO}_{4}\right)_{2}$ flocculation improves the treatment efficiency of flocculation.

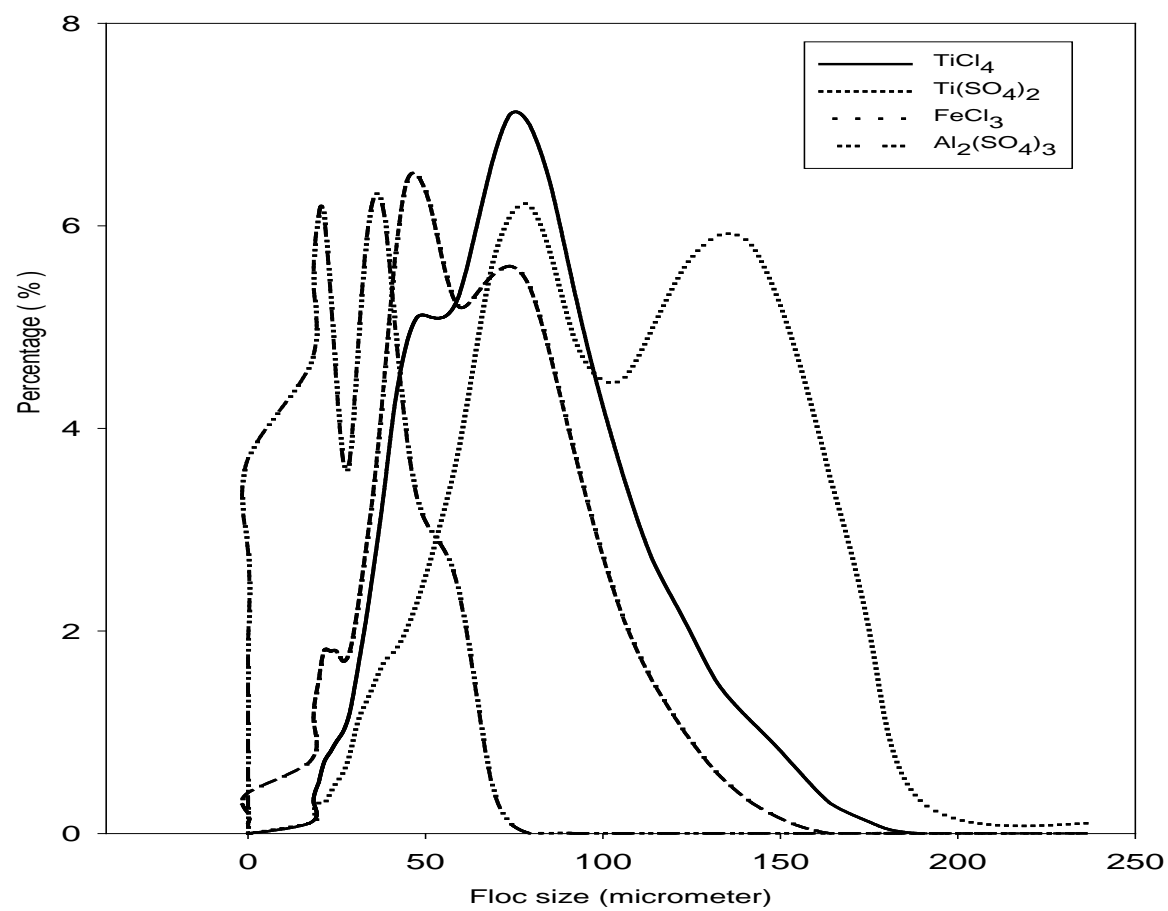

Figure 7. Particle size distribution of the settled flocs after different flocculation

\section{CONCLUSIONS}

The possibility of using titanium salts as alternative coagulants was tested and compared to the commonly used aluminium and ferric salts. Two types of titanium salts were studied; titanium tetrachloride and titanium sulfate. Titanium tetrachloride showed best removal of turbidity and colour than ferric chloride at all $\mathrm{pH}$ values. Titanium tetrachloride and ferric chloride both had the same DOC, UV-254 and SUVA removal at all pH values. Titanium sulfate showed best colour, DOC, UV-254 and SUVA removals compared with aluminium sulfate at all $\mathrm{pH}$ ranges. The alternative Ti- salts coagulants successfully removed organic matter to the same comparable extent as ferric and aluminium salts. In general, titanium tetrachloride showed the best turbidity removal, 
while titanium sulfate showed the best reduction of SUVA, UV-254 and colour compared with other coagulants at all $\mathrm{pH}$ values.

Dominating coagulation mechanisms for titanium tetrachloride and titanium sulfate are still to be investigated, since different precipitations reactions might take place at different $\mathrm{pH}$ even without flocculant addition. According to zeta potential measurements and visual observations, the most predominant coagulation mechanism was sweep coagulation or adsorption and sweep coagulation at $\mathrm{pH}$ higher than 8 , with doses above $30 \mathrm{mg} / \mathrm{L}$ for titanium tetrachloride and above $50 \mathrm{mg} / \mathrm{L}$ for titanium sulfate at $\mathrm{pH}$ higher than 6.

The coagulation performance for the titanium salts was less sensitive to $\mathrm{pH}$ (between $\mathrm{pH} 4$ and 10) and also can have an advantage in the secondary effluent pre-treatment at natural $\mathrm{pH}$. It is both cost-effective and environmental friendly to use the titanium salts not only in terms of removal of organic matter, but also in sludge reduction and producing titanium dioxide.

\section{REFERENCES}

Adin A., Soffer Y. and Ben Aim R. (1998). Effluent Pretreatment by Iron Coagulation Applying Various Dose-pH Combinations for Optimum Particle Separation. Water Science and Technology, 38(6), $27-34$.

Amy G.L., Siwrka R. A., Bedessem J., Price D. and Tan L.(1992). Molecular size distribution of dissolved organic matter. Journal of American Water Works Association, 84(6), 67-74.

Asilian H., Moradian fard Sh., Rezaei A.,.Mortazavi S. B. and Khavanin A. (2006). The removal of colour and COD from wastewater containing water base colour by coagulation process, International Journal of Environmental science and Technology, 3(2), 153-157.

Aziz H. A., Alias S., Adlan M. N., Faridah, Asaari and A. H. Zahari M. S. (2007). Colour removal from landfill leachate by coagulation and flocculation processes, Bioresource technology, 98(1), 218-220.

Bernhardt H. and Schell H. (1993). Control of flocculants by use of a streaming current detector (SCD). Journal of Water SRT-Aqua, 42(4), 239-251.

Childress A. E., Vrijenhoek E. M., Elimelech M., Tanaka T. and Beuhler M. (1999). Particulate and THM precursor removal with ferric chloride. Journal of Environmental Engineering-ASCE, 125(11), 1054-1061.

Corbitt R. A.,Crawford H. B. and Gleason D.(1989). Stand Handbook of Environment Engineering, McGraw Hill, New York.

DeWolfe J., Dempsey B., Taylor M. and Potter J. W. (2003). Guidance manual for coagulant changeover. American Water Works Association Press. Denver.

Edzwald J. K. and Tobiason J. E. (1999). Enhanced coagulation: US requirements and a broader view. Water Science and Technology, 40(9), 63-70.

Kapias T. and Griffiths R. F. (2005). Accidental release of titanium tetrachloride in the context of major hazards- spill behaviour using REACTPOOL. Journal of hazardous materials, 119(1-3), 41-52.

Lokshin E. P. and Belikov M. L. (2003). Water purification with titanium compounds to remove fluoride ions.Russian Journal of applied chemistry, 76(9), 1466-1471.

Mesdaghinia A., Rafiee M. T., Vaezi F., Mahvi A., Torabian A. and Ghasri A.(2006).Control of disinfection by products formation potential by enhanced coagulation. International Journal of Environmental Science and Technology, 2(4), 335-342.

Musikavong C., Wattanachira S., Marhaba T. F. and Pavasant P. (2005). Reduction of organic matter and trihalomethane formation potential in reclaimed water from treated industrial estate wastewater by coagulation. Journal of Hazardous materials, 127(1-3), 58-67.

Newcombe G., Drikas M., Assemi A. and Beckett R. (1997). Influence of characterized natural organic material on activated carbon adsorption: Characterized of concentrated reservoir water. Water Resources, 31(5), 965-972.

O’Melia C. R. Becker W. C. and Au K. - K. (1999).Removal of humic substances by coagulation. Water Science and Technology. 40(9), 47-54.

Pernitsky D. J. and Edzwald J. K. (2006). Selection of alum and polyaluminium coagulants: principles and applications. Journal of Water Supply: Research and Technology - AQUA, 55(2), 121-141.

Seo G. T., Ohgaki S. and Suzuki Y. (1997). Sorption characteristics of biological powdered activated carbon in BPACMF (biologicalactivated carbon-microfiltration) system for refractory organicremoval. Water Science and Technology, 35(7), 163-170.

Shon H. K., Vigneswaran S., Kim In. S, Cho J., Kim G. J. and Kim J.H.(2007). Preparation of titanium oxide $\left(\mathrm{TiO}_{2}\right)$ from waste water, Environmental Science and Technology, 41(4), 1372-1377. 
Upton W.V. and Buswell A. M. (1937). Titanium salts in water purification. Industrial and Engineering Chemistry, 29(8), 870-871. 